\title{
7 From Ignorance to Effective Inclusion: The Role of National Minorities within the Finnish Consensus Culture
}

\subsection{Prologue}

I am holding in my hand a rather new booklet, a booklet ${ }^{1}$ aiming to advise teachers in schools and kindergarten on how to treat Roma children in a correct and culturesensitive manner. The book aims at reducing barriers of cross-cultural understanding, and making teachers familiar with the Finnish Roma culture. The authors of the booklet underline that the Roma in Finland do have a different culture than the majority. Knowing this culture makes it easier for the teacher to take special care of the Roma child so that she or he will feel comfortable in the kindergarten and school. On page four of the booklet it explains that in Roma families there is a very traditional gendered sharing of household-work: women take care of the kitchen and house and men earn the living. On page six taboo topics are listed and the reader is informed that such issues as sexuality and normal physical activities should not be spoken about. The Finnish Roma are also told to have a different understanding of time, and this should be known by teachers. The booklet goes through specific features of Roma culture and also covers the term of 'avoiding'. When a Roma kills or hurts another Roma, the perpetrator's family needs to avoid by all means the family of the victim: this is explained as a means to pay respect to the victims' family and therefore, it is noted, for example that children of the two families cannot attend the same school or kindergarten. After the rather culturalising tone of the booklet, it then stresses on page eight that 'Not all Roma children are bound by culture!' What does this kind of booklet tell us about Finnish society, the inhibited understandings of differing cultures within and its approach towards minority cultures?

This article discusses power relationships tied to the differing status positions of minority groups in a society in which decision-making is based on consensus: It addresses the ambivalence in a polity torn between a strong governmental (and societal) commitment to shared power in the name of equality and a weak inclination toward accommodation of diversity. The empirical material stems from research with two national minorities in Finland, the Sámi and the Roma. The main question concerns participation in the creation of the agenda behind decision-making processes: why certain interests (of minorities) do not find a way

1 Romanilapsen ja -nuoren elämää, tapoja ja kulttuuria, Ovet Auki -projekti, Kalevaprint 2007, available also: http://www2.luovi.fi/ovet_auki/documents/opettajille.pdf, accessed in August 2010. 
to be articulated in the Finnish public sphere and whether the 'closed' agenda of what can be articulated leads to non-participation among minority members on the one side and strengthens systemic and structural discrimination on the other side.

\subsection{Equality mainstreaming or societal strait-jacket?}

In her article titled 'The unfitting Sámi' (in orig. 'sopimattomat saamelaiset'), Marjut Aikio (2006:21) argues that racism in Finland takes other forms than elsewhere. Reframing Erik Allardt's 40 year old statement, she goes on saying that in Finland any difference is in a systemic manner illicit and that Finnish society can only deal with a unity. According to her, that is the case, even though this unity is generally recognised as artificial. An artificial homogeneity is conceived as a convenient base for a conflict-free society. Similar arguments can be found in a book by Boxberg and Heikka (2009) who contend that there is not even a need for corruption in a country like Finland where the power relations are so clearly defined that power must not be articulated publicly.

Where power is invisible, it works most effectively. According to Garland (interpreting Foucault) power refers to 'the various forms of domination and subordination and the asymmetrical balance of forces which operate whenever and wherever social relations exist' (Garland 1990:138). '[P]ower reaches into the very grain of individuals, touches their bodies, and inserts itself into their very actions and attitudes, their discourses, learning processes, and everyday lives' (Foucault 1980:39). Steven Lukes (1974/2007) discusses in his groundbreaking book Power - A Radical View what he calls the third dimension of power or a radical view on power. This is the power 'to prevent people, to whatever degree, from having grievances by shaping their perceptions, cognitions and preferences in such a way that they accept their role in the existing order of things'.

Power is something that can be associated with a term that Pierre Bourdieu has called habitus: 'the habitual, patterned ways of understanding, judging, and acting [...]', '[...] habitus is what gives the groups they compose consistency' (Terdiman 1987:812-3). This habitus concept is useful when explaining that there are forms or modes of power, which silently formulate people to the norms of how they are to be, to behave, to feel without open or visible coercion forcing them to transform. To put it bluntly, habitus describes such forms of power which operate in the invisibility without causing any reasons to object to them. If there is such a thing as a consensual power sphere building on agreements by people guiding them without forcing them to follow certain life modes, the question then raised is how can we understand power's 'work' in a society characterised by diversity? Lukes' third dimension can be used to describe the situation of a society as a whole where 'there can be no personalities that are formed independently of [power's] effects' 
(Lukes 2007:92). This means that power affects all members of a society but the question in this contribution is how it affects people in different status positions. So what is then the case when we move to think about power in the context of minority-majority relationships in a democratic setting? My assumption is that power 'works' differently among those belonging to a titular nation and those who identify themselves as minority members.

Bud Khleif (1993) introduced the concept 'minoritised' which he uses in order to illustrate that no one chooses to have less power. This means that nobody wants to belong to a minority if there are chances to have a position with more power. The word also implies the existence of an active element: somebody makes someone a minority, it is not in the nature of some people to be in a marginal position. They are marginalised and through the process of marginalisation, they become minoritised. The question is who marginalises 'them' and why, can obviously be answered with the aid of Michael Mann (1999) or Claus Offe (1996) who point to the democracy deficit which is inherent to any democratically formed polity. In its core, any democracy is constituted by undemocratic means but the level of democracy, meaning rule by people, can grow or deepen to include more and more people, ideas, and forms of power. ${ }^{2}$ According to this understanding, those who are excluded from a national identity building process and bestowed a position of being the 'other' in the setting of a generally accepted national unity, constitute the segment called minorities. There are different kinds of minorities and their relationship to the segment deemed the majority varies: whereas some are closer to power, others are heavily marginalised.

This article discusses these varying power relationships tied to the differing status positions of constructed minority groups. As a case study, it addresses the ambivalence in the Finnish polity torn between a strong governmental (and societal) commitment to shared power in the name of equality and a weak inclination toward the accommodation of diversity. The empirical material stems from my long-term research with two national minorities in Finland, the Sámi and the Roma. The main question concerns participation in the creation of the agenda behind decision-making processes: why certain interests (of minorities) do not find a way to be articulated in the Finnish public sphere and whether the 'closed' agenda of what can be articulated leads to non-participation among minority members on the one side and strengthens systemic and structural discrimination on the other side. What does it mean for minorities' perspectives when the context of identity politics is ambivalent: when the official policy stresses equality but the public atmosphere is hostile towards difference?

2 See here also Hannah Arendt on how new ideas and agendas get into the public sphere which is controlled by a certain segment of a society. 


\subsection{Minorities in Finland}

For a long time, Finland has been described as one of the most homogenous countries of Europe (Saukkonen 2010). It was the low number of foreign-born persons living in Finland, which made this argument a truism. Also the selfimage of Finland continues to underline that Finland is a culturally and socially homogenous country where all difference is considered as an exception (Lepola 2000). Even if the self-image hasn't changed, the population structure has: Between 1990 and 2009, the number of foreign citizens legally residing in Finland increased six-fold. The number of foreigners in Finland in the beginning of the 1990s was 26,300; today 155,700 foreign persons reside in Finland (Tanner 2011). According to the 2008 statistics, Finland had the seventh lowest proportion of foreign citizens in total population of all the EU-27 countries. One half of the foreign citizens live in the capital city area. ${ }^{3}$

The official state languages of Finland are Finnish with 4,836,183 speakers and Swedish with 289,951 (5.4 per cent) speakers. ${ }^{4}$ The official national minority languages include three different Sámi languages (Northern, Inari, and Skoltsámi), Romani, Tatar, Russian, Yiddish and Karelian. ${ }^{5}$ The constitution also guarantees rights to the speakers of each of the Sámi indigenous language which altogether have 1778 (0.03 per cent) registered mother tongue speakers. The number of Sámi people is estimated to be 9400 persons out of whom 60 per cent live outside the Sámi homeland territories in which Sámi enjoy specific rights. ${ }^{6}$ The Roma and other language groups' rights are laid down in a separate law on language. The number of Roma speakers is estimated at 4000, which amounts to less than 50 per cent of the total Roma population in Finland (Granqvist 2006; Hedman 2008).

3 Statistics Finland: The population development of regions is going into different directions, published 30. September 2010.

4 The Swedish and Finnish language should enjoy similar protection which is further clarified by law. The municipalities in Finland can be either monolingual Finnish, monolingual Swedish, bilingual with a Finnish majority, bilingual with a Swedish majority or bilingual on voluntary decision. A municipality is designated bilingual if the population includes both Finnish and Swedish speakers and the minority comprises at least eight percent of the population or at least 3000 persons. A bilingual municipality is designated unilingual if the minority comprises less than 3000 persons and its proportion has decreased below six percent. Language Act 423/2003, chapter 1, sector 5 .

5 The European Bureau for Lesser Used Languages and the Advisory Committee of the Framework Convention on National minorities consider also the other official language of Finland, namely Swedish, as de facto minority language. Finnish European Bureau for Lesser Used Languages, http:// fiblul.huset.fi/etusivu.

6 Saamelaiskäräjät 2008, Koulutusraportti 1/2008 (The Education Report of the Sámi Parliament of Finland). 
Other languages account for 3.6 per cent of the population of Finland. There are now 30 different foreign-language groups with at least 1000 speakers in Finland. ${ }^{7}$ Over the last decade, due to immigration, the number of Russian speakers has increased to the largest foreign language in Finland with 51,683 speakers. ${ }^{8}$

The ethnic composition follows the lines of language communities. In 1995, the Sámi as an indigenous people secured a constitutional reform for cultural autonomy in their home region. ${ }^{9} 90$ per cent of the land in the Sámi homeland area is owned by the state: the constant extractive industries, notably mining and forestry, have created a situation in which one cannot gain a livelihood with the traditional practices of reindeer herding and fishing. At present 70 per cent of the Sámi children aged 11-24 live outside the Sámi territory and lack education in their mother tongue (Saamelaiskäräjät 2009).

The Roma children face several difficulties starting with access to education and continuing with racism. 70 per cent of the Roma still value highly their own mother tongue, but at the moment only 8.5 per cent of Roma children enjoy the right to mother tongue teaching provided by the law (Hedman 2008). Meanwhile, according to the Finnish Association of Russian-Speaking Organisations FARO, Russian speakers, very often due to discrimination, avoid using Russian in public places. There are also 10,647 Somali speakers in Finland who, along with others who have a differing appearance, face racism both at work and in public.

The Non-Discrimination Act was adopted in Finland in 2004. ${ }^{10}$ Its material scope is wide and it covers several grounds of discrimination: age, ethnic or national origin, nationality, language, religion, belief, opinion, health, disability, sexual orientation or other personal characteristics. Different governmental bodies monitor the realisation of that law: The Ombudsman for Minorities (ethnic origin) supported by the Advisory Body for Minority Affairs, the Discrimination Board, the Parliamentary Ombudsman and Chancellor of Justice, the Ombudsman for Equality (sex, gender and gender identity), the Ombudsman for Children and the Sámi Parliament. Discrimination

7 Statistics Finland: Review of the population structure of Finland 2009, published on 30. September 2010, http://www.stat.fi/til/vaerak/2009/01/vaerak_2009_01_2010-09-30_kat_001_en.html, accessed in February 2011.

8 Finland has a traditional 'old' Russian minority of ca. 3000 persons which enjoys special protection. Finland has made a distinction between the Old Russians and the New Russians. For instance, Finland has considered that the Framework Convention for the Protection of National Minorities de facto covers the former but not the latter group.

9 The section 121 of the constitution says: 'In their native region, the Sami have linguistic and cultural self-government, as provided by an Act.' The Act on the Sami Parliament was enacted on 17.07.1995, last amended 30.12.2002, (974/1995), http://www.finlex.fi/en/laki/kaannokset/1995/en19950974.

10 Yhdenvertaisuuslaki / Non-discrimination Act 20.01.2004/21, entered into force 01.02.2004, last amended 20.02.2009/84. Translated with amendments until January 2010, http://www.finlex.fi/en/ laki/kaannokset/2004/en20040021.pdf, last visited February 2011. 
in the field of employment is monitored by several labour protection districts. In addition to the Advisory Board for Minority Affairs, there are also Advisory Boards for Sámi Affairs, for Ethnic Relations, Romani Affairs, Disability ${ }^{11}$, Rehabilitation Affairs, Youth Affairs and Ageing and Pensioners's Affairs.

\subsection{Finnish commitment to equality and the practice of ignorance}

The Finnish ministries, municipalities and towns follow a horizontal approach that addresses discrimination on the grounds of ethnic origin, age, language, religion or belief, disability, sexual orientation, and multiple discriminations (Aaltonen, Joronen and Villa 2009). This horizontal approach ${ }^{12}$ is tangible in the Finnish revised Non-Discrimination Act, which puts the principle of mainstreaming all fields of public administration in its centre, and applies non-discrimination policies to all fields of societal life. ${ }^{13}$ The primary mainstreaming tools consist of developing non-discrimination programmes for different authorities, the public sector and private sector, awareness raising, education and developing methods of detecting discrimination (Mahler, Mihr and Toivanen 2009). It has been argued that when nondiscrimination and mainstreaming are underlying principles they can, especially in such a consensual society as Finland, be ignored easily (Mahler 2009). It is important to remember that even in the 1980s, human rights was a 'non-issue' due to the political circumstances entailed by Finland's close and complicated relationship with the Soviet Union. ${ }^{14}$ Human rights as a concept was interpreted in a socialist manner as a political tool of the 'West'. After Finland joined the Council of Europe in 1991 and the European Union in 1995, human rights has become a popular concept: the commitment to human rights standards can be found in many policy papers and governmental proposals. The commitment to human rights and non-discrimination are today found in almost every single Finnish policy paper or educational plan. For example, on the internet page of the Ministry of Foreign Affairs it says: '(...) Finland belongs to a value community, which is based on democracy, the rule of law, and respect for human rights. One of the purposes of Finland's foreign policy

11 The correct name of the institution dealing with concerns of disabled is National Council on Disability.

12 Horizontal approach means that the government opted for a broad legislative approach rather than a specific law. The main tool of combating discrimination according the horizontal approach is in the mainstreaming of human rights provisions. Finland has since the adoption of the Non-discrimination Act, followed the principle of mainstreaming in all fields of administration.

13 Equality and non-discrimination: Definitions and Concepts, see www.equality.fi, accessed in May 2010.

14 On the development of human rights law and politics in Finland, see i.e., Scheinin 1989. 
is to also emphasise the importance of these values internationally.' ${ }^{15}$ The new core curriculum is introduced by the National Board of Education with the emphasis on '(Its) underlying values of basic education are human rights, equality, democracy'. ${ }^{16}$

According to recent polls, Finland indeed reveals an ambivalent picture of the nation. When on the one hand Finnish people value high levels of equality and they see it as one of the key markers of Finnish society, ${ }^{17}$ the attitudes of Finnish people towards foreigners and all other minorities have grown more rigid over the last decade (Jaakkola 2009). According to Eurobarometer $296,{ }^{18} 15$ per cent of the population in Finland has experienced discrimination or harassment during the last year. Numerically most discrimination was experienced according to age and sex, whereas relatively most discrimination was experienced by members of ethnic groups. A larger group has witnessed discrimination (30 per cent) than report to have been subjected to it. 65 per cent of Finnish people felt that discrimination on the grounds of ethnicity is normal or very normal and ethnic discrimination was considered as the most common form of discriminatory behavior. Regarding causes of discrimination, 49 per cent believed that sexual orientation caused discrimination, 45 per cent attributed discrimination to disability and 43 per cent thought that age caused discrimination. Only 27 per cent thought that religion and 25 per cent that gender leads to discrimination. In 2008 the results of another Eurobarometer ${ }^{19}$ dealing with discrimination were published. Here Finnish people reported that they had experienced discrimination on the grounds of age and ethnicity (21 per cent), disability (17 per cent), religion or belief (11 per cent) and sexual orientation (7 per cent), with 21 per cent reporting multiple sources of discrimination.

There is, however, very little litigation involving racist crimes and discrimination compared to the amount of potential cases, in comparison to these percentages. The major problem is that in Finland, reporting the case to the police, an ombudsman or to a lawyer (or in the case of discrimination at work to the occupational safety and health representative or a union representative) in order to file a lawsuit against the perpetrator, is exceedingly difficult for

15 On Finlands foreign and security policy: http://formin.finland.fi/public/default.aspx?nodeid=322 80\&contentlan=2\&culture=en-US, accessed in February 2011.

16 Finnish National Board of Education: New Core Curricula, http://www.oph.fi/english/sources of_information/articles_and_presentations/101/new_national_core_curricula, accessed in February 2011.

17 Suomen Gallup: Suomalaiset väheksyvät poliittisia oikeuksiaan (Finns downgrade their political rights). Research by the Finnish Gallup for national Broadcasting Company YLE, published 6.12.2007, see http://yle.fi/uutiset/kotimaa/2007/12/gallup_suomalaiset_vaheksyvat_poliittisia_oikeuksiaan_259633.html, accessed in May 2010.

18 Discrimination in the European Union. Perceptions, Experiences and Attitudes. Special Eurobarometer 296.

19 Discrimination in the European Union. Analytical report. Flash Eurobarometer 232. 
people who are by definition marginalised (Aaltonen, Joronen and Villa 2008:39). For example, the Office of the Ombudsman for Minorities tackled 737 cases of potential discrimination in the year 2007, but the police received only 47 suspected discrimination crime cases (ibid p. 36; Vähemmistövaltuutetun vuosikertomus 2007). Another problem is that the recognition of racism and discrimination is exceedingly difficult for members of a majority who do not want to challenge the image of the country as a harmonious space. This is linked to the fact that forbidding discrimination (litigation on various grounds of discrimination) has been less attractive in Finnish society than giving policy advice on equality (Aaltonen, Joronen and Villa 2009). Finnish people do know their rights better than many other citizens of the EU, but the hurdle of bringing cases to court is high: discrimination cases are a particular rarity for Finnish judges (ibid). The inactivity to evoke minority rights and anti-discrimination law can be at least partly explained by the lack of human rights education in Finland: the majority population neither knows and recognises difference nor understands the reasons for differential treatment (Toivanen 2007).

The Finnish state and the municipal authorities view human rights and nondiscrimination activities positively but they have taken a passive stand (Aaltonen, Joronen and Villa 2009:15). The longer that authorities remain inactive, the more invisible difference is at stake: Gender, sexual minorities, religious groups or the Sámi do not seem to require non-discrimination action. When it comes to visible phenomena such as disability, race and immigration, authorities are more prepared for active policies. The common attitude among authorities towards minorities, often implicit, but sometimes expressed explicitly, is that minorities should not complain because the state is doing everything possible to enhance their situation. For example, in the Finnish Human Rights Forum 2009, the Minister for Foreign Affairs Alexander Stubb was visibly upset by the claim of some people from the audience that the freedom of speech is regularly infringed in Finland. He said: 'But really, do you know anybody in Finland who could not say whatever they wanted in this country?'20

Finland has strived to become ranked as a model country for minority treatment. The power hegemony is tangible in the way in which the government engages in international arenas in the development of minority protection. The rights of minorities are also stipulated in the reformed constitution of 1999 . The belief among those holding power to the just regulation and shared power is very strong and the myth of the equal society is as strong as the belief in it. Because the majority of Finns, including many who are in a marginalised position, accept as

20 Personal notes 01.10.2009. Human Rights Forum is organised by the Finnish League for Human Rights to address human rights in Finland. The event is popular for Members of Parliament who all can show off their commitment to human rights there. 
true that societal peace can be best maintained by believing in the general shared commitment to equality, bringing up themes which would challenge this view is fraught with difficulty. Finland is leading the European statistics on bullying in the workplace, the number being twice as high than the European average ${ }^{21}$ and there are reports underlining the situation that in Finland people try not to express difference or differing opinions in order to maintain the so-called 'societal peace' or an image of such (Vartia et al. 2008). If you belong to a group that has become minoritised, whether sexual and gender minorities, visible immigrants or refugees or national minorities, both institutional and individual power relationships look different than the perspective of people belonging to the 'mainstream', majority population. In the following I will tackle these challenges of addressing power in a consensual society with a rather short history of transparent democratic structures by using the examples of two different minorities, the Roma and the Sámi.

\subsection{The Sami and the Roma in Finland: Two unlike minority populations}

In this section, I will use the case studies of the Finnish Roma minority ${ }^{22}$ and those Sámi indigenous people who live in the Finnish area of Sápmi ${ }^{23}$ to illustrate something that could, according to Lukes (2005), be called invisible power. Invisibility means here, that power takes such forms that it does not need to be openly executed but it is hidden in structures of society and influences the self-perception and strategies of people. We could speak here also about structural or systemic discrimination as the official names go. I however, think that using the term discrimination here would distract from the situation where the intent to discriminate is not obvious, not even to those with discriminatory attitudes and behaviour. The act of discrimination is so tightly ingrained within normal thinking and behaviour that people who are discriminated against may not be aware of it.

21 YLE uutiset, Suomi on työpaikkakiusaamisen ykkösmaa (Finland is the leading country in bullying at work), 22.08.2008, http://www.yle.fi/uutiset/kotimaa/2008/09/suomi_on_tyopaikkakiusaamisen_karkimaa_320619.html, accessed in February 2011.

22 It is estimated that out of 20 million Roma people, 10 million live in Europe. Whereas the Finnish Roma community is small in numbers, they have played a crucial role in establishing European Roma organisations (such as the European Forum for Roma and Travellers under the auspices of the Council of Europe) which struggle for human rights issues for Roma.

23 Altogether ca. 100,000 Sámi people reside in four Northern countries, Norway (70,000), Sweden $(18,000)$, Finland (10,000) and Russia (2000). They maintain institutions and organisations, which operate across borders and actively take part in international indigenous peoples' human rights activities, e.g. through the UN Permanent Forum for Indigenous Issues. 


\subsubsection{Difference rights for Sámi vs. sameness rights for Roma?}

The Roma and Sámi are very different ethnic groups in Finland, whether one looks at their legal standing, self-image or cultural expression. ${ }^{24}$ I have chosen these examples for several reasons. Firstly, because they play different roles in the Finnish public sphere and secondly because they claim different types of recognition and rights: the Sámi are officially recognised as the indigenous people of Finland and the government has tied itself to international agreements and national law to protect their traditional way of life. The Finnish Constitution was reformed in 1995 to include fundamental rights for Sámi people to maintain and develop their culture and language (Finnish Law 969/95). In the same reform, the government committed itself to 'secure the realisation of fundamental rights and human rights'. The aim of these changes was to 'guarantee the maintenance of the distinctive Sámi culture' (Government's Bill to Parliament 309/93). The concept of culture was interpreted to include the traditional Sámi livelihoods such as fishing, hunting and reindeer herding (ibid, p. 65).

The Sámi Parliament, an elected body, was foreseen as the institution, which would develop and implement the right of Sámi people to promote cultural autonomy. Article 1 of The Act on the Sámi Parliament stipulates that 'the Sámi, as an indigenous people, have a linguistic and cultural autonomy in the Sámi homeland' (Finnish Law 974/1995). This acknowledgment is based on the International Covenant on Civil and Political Rights of 1966 (UN 1966a) and its article 27 protecting minorities ${ }^{25}$ as well as on existing international law on the rights of indigenous peoples. ${ }^{26}$ The Sámi claim these rights and stress the importance of indigenous autonomy (including the right to continue with traditional ways of livelihood). They have a rather strong political institution, the Sámi Parliament, representing the interests of the whole group. ${ }^{27}$ The Sámi Parliament has in its statements made clear that it strives for recognition of Sámi as a distinct people and claims the right to be treated differently, according the specific needs of Sámi people.

24 It should be noted, that whereas Sámi can rather easily follow the assimilation strategy and privately choose to become a non-Sámi (for whatever reasons); this is not similarly possible for many Roma who often have a phenotype differing from the Finns.

25 However, the Finnish government has refused to acknowledge Sámi as a people in the sense of article 1 of the same convention in fear that this recognition would automatically entitle them the right to self-determination in issues concerning natural resources. The president of the Finnish Sámi Parliament, Klemetti Näkkäläjärvi (2009), criticised heavily the Government and said that ' $[t]$ he opinion of the Finnish Government reflects a deplorable nationalistic tradition based on the idea of one people in one state.'

26 Such as the International Labour Organization's convention 169 from the year 1989. Finland has, however only signed this convention but not been 'able' to ratify. I will return to this debate later in this article.

27 Even though it should of course be said that the organisation is by no means accepted by all Sámi as 'the' legitimate representative. 
The Roma are recognised as a language minority in the Finnish Constitution (731/1999, Article 17) next to the Sámi and other language minorities as one of the groups to be protected under the minority rights clauses. Finland has acknowledged the status of the Roma as a national minority, notably in the explanation to the Framework Convention on National Minorities (Council of Europe 1995; Ministry of Foreign Affairs 2010). The Finnish Romani Forum was established under the premises of the Council of Europe's European Forum for Roma and Travellers ${ }^{28}$ but until today none of the bigger Roma organisations have joined the envisioned umbrella organisation due to internal conflicts and competition over cooperation. ${ }^{29}$ Otherwise, the Roma are represented in the governmental structures through the Advisory Body for Roma Affairs (RONK) and have their own centre at the National Board of Education for Roma education matters. Also, the RONK and the Finnish Romani Forum can be regarded as organisations which are motivated by majority interests to get Roma representation 'settled', to find a body 'to talk to'. In addition there are several Roma NGOs active in different societal and cultural fields in Finland, especially ones motivated by religious grounds. The Roma underline the need to reach standards of living similar to the majority population; therefore it can be reasonably argued that they claim sameness rights, rights for equal opportunity (whereas Sámi ask for different treatment). The main problem for the Roma is a deeply rooted socio-economic disadvantage caused by discrimination and intolerance towards the Roma as an ethnically separated group. They are much less inclined to claim cultural and language rights as opposed to claims related to economic and social inclusion. ${ }^{30}$

\subsubsection{Defining minority identity in a majority context}

The official definition of who can claim Sámi identity follows linguistic criteria even though no active language knowledge is required. Section 3 of the Act on the Sámi Parliament defines that a Sámi as a person who considers him or herself a Sámi, provided that this person has learnt Sámi as his or her first language, or has at least one parent or grandparent whose first language is Sámi; and is a descendant of a person who has been entered into the population register as mountain, forest or fishing Lapp, or at least one of the parents has or could have been registered as an elector for an election to the Sámi Delegation or the Sámi Parliament (Finnish Law 974/95). It is the Finnish law which defines who can belong to the Sámi community

$28 \mathrm{http}: / /$ www.ertf.org, last accessed in May 2010.

29 See the list of smaller local member organisations: http://www.romanifoorumi.fi/index. php?page=jaesenjaerjestoet , last accessed in May 2010.

30 See also Nordberg in this publication. 
and even though this has been challenged by such persons who do not fulfil the criteria or cannot prove that they fulfil it, it has remained unchanged.

The Roma identification is more a question of heritage and blood relations. For Roma, whose language was until the 1980s (and for some elderly especially still today) a secret language, there is very little information about the level of their language skills, which definitely do not delineate the Roma identity (Hedman 2009b). The number of Roma speakers in Finland is estimated at 4000 (less than 50 per cent of the Roma in Finland) (Hedman 2008; Granqvist 2006). This number contains both fluent and much more passive speakers. Numerically the two minorities reach similar numbers: there is no official statistics but the Sámi constitute a group of around 9000 persons and the three different Sámi language communities (the Northern Sámi, Inari Sámi and Skolt Sámi speakers) have altogether 1778 (0.03 per cent) mother tongue speakers. ${ }^{31}$ The Sámi homelands are in the northernmost part of Finland and even though 70 per cent of the Sámi children live outside the homeland, their rights are most-effectively protected only in the Sámi home territory. Meanwhile, 10,000 Roma are scattered throughout the country and some 3000 of them emigrated in the $1960 \mathrm{~s}$ and 70s to work and live in Sweden. The protection of the Roma is equally challenging in every corner of the country.

\subsubsection{The public sphere as a hegemonic setting co-defines minoritisation}

It might be easy to conclude that these two national minorities do not share anything in common, but in fact they do: Both are developing their own strategies to cope with Finnish majority rule and have to deal with the fact that their 'own interests' cannot enter the Finnish public sphere without a certain kind of cultural translation which is, in its deepest meaning, a political translation of their own group interests to a language which is understood by the majority public. The Finnish majority has control over the framework and premises for Sámi and Roma identity claims and sets the limits regarding what they can ask for. The discrepancy is between what the Finnish government says it is doing in the field of minority rights with the reality of how these groups are treated. ${ }^{32}$

A prime example about the difficulty of harmonising the self-image as a minority rights friendly country is the question of the settling of rights of the Sami people to natural resources and livelihoods. Another example is the failure to guarantee education of Roma people. Both these examples testify, as it should become obvious

31 Statistics Finland > Population > languages, of 27.3.2009.

32 See e.g. for the legal sphere the concluding observation by the Advisory Committee of the Framework Convention on National Minorities which stress the incredible discrepancy between laws on papers and legal action in Finland, under http://formin.finland.fi/public/default.aspx?contentid=67435, accessed in May 2010. 
in the next section, about the unwillingness of the Finnish state to accept the specific demands of minorities and to recognise their needs for differential treatment.

\subsection{Sámi and the denial of the right to their own culture}

The Sámi homelands are located in Lapland, the northernmost part of Europe in the area of the Norwegian provinces of Finmark, Troms $\emptyset$, part of Nordland, the northernmost part of Sweden and Finland, and the Kola Peninsula of Russia. About 45,000 Norwegian, 16,000 Swedish, 10,000 Finnish and 2000 Russian citizens are Sámi. The number of people who identify as Sámi has grown during the last decade and the trend is presently continuing (Toivanen 2003:205). The Sámi people are recognised as national minorities in all three Nordic countries. ${ }^{33}$ There are nine living, yet comparatively very small, Sámi languages. Northern Sámi has the most speakers, and because it is spoken in Sweden, Norway, and Finland, and it has gained the status of the Sámi lingua franca. In Finland, in addition to Northern Sámi, Skolt and Inari Sámi are official languages. Even in their traditional homelands, the Sámi constitute a minority, and this was already the case at the beginning of the twentieth century.

In Finland, Sámi history is full of conflicts with the majority nation. Not only have they been marginalised in every manner of life through law and order, be it laws regulating reindeer herding, fishing or education, but also in the socio-psychological sphere of creating 'the other' against which Finnish identity could be constructed. The national romantic author, Zacharias Topelius (1943; orig. 1875) describes the Sámi, in his book Our Land (previously read by every pupil at elementary school level), as 'naïve, dirty, short, clumsy forest dwellers who would be jealous, foxy, drunk and unable for reasonable cooperation'.${ }^{34}$ Denying that the Sámi could be a rational people with their own history has well served the nationalist interests of the titular nations in all four countries. Also, the claim that the Sámi would not have any understanding about ownership - as Karl Nickul (1984:48) said: 'Sámi were believed to have a similar relationship to land as to water and air' - has for decades legitimated the fact that the Sámi home lands were occupied without compensation by the Nordic states.

33 In the Finnish Constitution, Section 17 (3) and in the Norwegian Constitution, Section 110 (a). The Swedish Constitution does not contain a section on Sámi but apparently the new proposal would include the protection of Sámi as an indigenous people, see http://www.galdu.org/ web/?odas=4541\&giella1=eng, accessed in May 2010.

34 The same adjectives seem to continue to live in stereotypic chat room writing on the internet. Reading the local Finnish newspaper of the district of Lapland, one can find sentences such as 'Bitter, jealous, uncooperative drunk who demand Finnish land in the name of Sami, oh goddamnit, take the leather trousers and pull them over your head!' [in orig. 'Katkeria, kateellisia, yhteistyökyvyttömiä juoppoja vaatimassa saamelaisuuden nimissä itselleen Suomenmaata, voi jumalauta, ota ne nahkahousut ja veä ne pääs yli!' ], in Lapin kansa, keskustelu-palsta 14.02.2010. 
At the same time, since the 1970s, all Nordic governments have in the international arena acted as helpers and preservers of Sámi culture. As James Anaya (2010), the United Nations Special Rapporteur on the Situation of the Human Rights and Fundamental Freedoms of Indigenous People, stated recently ' $t$ the Sami people and the Nordic countries took a leading role in developing international standards and programs concerning indigenous peoples [...]'. The Finnish Government plays a leading role in developing international law but, interestingly, implementing the laws back home, seems far less pressing a concern.

\subsubsection{International law and ways to sidestep its requirements}

The ignorance of the Finnish state towards the Sámi - the right of the Sámi as an indigenous people to maintain their culture - can be concretely observed by following the Finnish Government's 'efforts' to ratify the International Labour Organisation's (ILO) Convention 169 concerning Indigenous and Tribal Peoples in Independent Countries (ILO 1989). From the viewpoint of the Finnish government, land rights questions are especially problematic. The lands formerly owned by Sámi villages are now 90 per cent in state-ownership (Korpijaakko 1989). Article 7 of the convention says that indigenous peoples have the right to 'decide their own priorities for the process of development as it affects their lives, beliefs, institutions and spiritual well-being and the lands they occupy or otherwise use, and to exercise control over their economic, social and cultural development'. Since 1989 several national expert groups and committees have dealt with the question of how the ratification should be completed and what kind of legal changes it necessitates. ${ }^{35}$ One committee after another has come to the conclusion that the matter is difficult. Indeed, none of the expert bodies has been able to offer a concrete proposal about how to proceed, while the same matters have been in the centre in each report, namely the land rights. In 2006 when Finland was striving for a permanent seat at the United Nation's Human Rights Council, Finland promised to ratify the ILO 169 without delay if a seat was allocated to the country. In 2011 Finland obtained a permanent seat but has not yet ratified the convention. Various monitoring bodies of international human rights treaties have continuously raised criticisms towards the government's failure in this matter. For example, the Committee on the Elimination of Racial Discrimination, held in its March 2009 Concluding Observations on Finland, the following concerns:

35 For example the commissioned reports by Pekka Vihervuori in 1999, by the so-called Pokka Committee in 2000, by Juhani Wirilander in 2000, and by the so-called Land Rights Research Project by four Finnish scholars from the Universities of Oulu and Lapland. 
The Committee reiterates its concern about the limited progress achieved in resolving Sámi rights issues and the State party's failure to adhere to the International Labour Organization Convention No. 169 concerning Indigenous and Tribal Peoples in Independent Countries. The Committee renews its appeal to the State party to find an adequate settlement of the land dispute together with the Sámi people and its recommendations that it adheres to ILO Convention No. 169 as soon as possible (CERD/C/FIN/CO/19).

In Finland, the public argumentation is not talking about ignorance; instead the various efforts and the commitment of the government (after government) to settle the rights in the ways that meet international requirements is stressed in the public sphere. The Sámi Parliament receives a regular reassurance that a solution is just about to be finalised (Näkkäläjärvi 2010). The case of Sámi rights to natural resources has been ignored with arguments that the rights of the indigenous people may not go before the rights of Finns residing in the Sámi homelands. In 2009, the Minister for Agriculture Sirkka-Liisa Anttila, stressed that, as a response to the promise by the Minister of Justice, Tuija Brax, the government will ratify the ILO 169 convention during this government period. However, she will expect that evidence of a unanimous opinion on the ratification in Lapland will be presented before it will be accepted. Anttila also contended that the opinions of the other people who had settled in Lapland must be equally heard, not simply the views of the Sámi Parliament. ${ }^{36}$

There is no doubt that the case is complicated: since the $18^{\text {th }}$ century people other than Sámi have settled in the Sámi area, later and notably after the Second World War since the state has paid additional salary to Finnish authorities who have accepted to take jobs in periphery regions such as Lapland (Lehtola 2004). Most of the teachers, municipal authorities, city mayors, post officers, police officers, and healthservice personnel etc. are Finns, migrating from the South of the country. Some of these have by now indeed lived for generations in the area which today is called the Sámi homelands and quite a few of them have adopted parts of the Sámi lifestyle, i.e., reindeer herding, hunting and fishing. The situation is even more complicated by the fact that Sámi used to migrate freely in the area where we today find the state borders of Norway, Sweden, Finland and Russia. This means that there are Sámi living in Finnish Lapland who moved there later than some of the Finnish people who moved there from the South.

All these complications and the question of who came first are, if we would recognise the Sámi as an indigenous people, irrelevant. The Sámi 'earn' the right to different treatment and specific protection because they have a different lifestyle, which they want to preserve. Solely on this basis, they should be recognised as a

36 Pääkirjoitus ‘Umpisolmu ei auennutkaan’ (An overhand knot did not open after all), 5.9.2009 Lapin Kansa. 
people and if Finland wishes to continue having an indigenous group, quite radical positive rights are necessary: a total guarantee that the grazing areas of freely moving reindeer remain untouched (by the Finnish forest and mining industry), fishing and hunting rights should be more profitable for Sámi before all other habitants and especially before tourists, and regarding land usage matters, the Sámi Parliament should not only get consulted but decisions on land use should be made jointly with the Parliament possessing equal powers to the state.

Similar questions came up in the drafting process of the Nordic Sámi Convention. The Finnish government together with the Norwegian and Swedish governments cooperated with the national Sámi Parliaments of all three countries on a convention, which would guarantee a similar level of protection for the Sámi in all three countries. The work took several years, but after the draft was finalised in 2005, the Finnish government decided that it could not accept the drafted compromise and there would be a need to reform it. As a consequence, the Nordic Sámi Convention has rested (together with the ILO 169) under the auspices of the Ministry of Justice, where a Committee is apparently working on it but no news about the state of affairs has entered the public sphere. Political scientist with Sámi roots, Rauna Kuokkanen (2008), has in her blog writing posed the question whether the state will deploy delay tactics 'until the problem [the Sámi] disappear'. Martin Scheinin, who was a Finnish member of the team drafting the Nordic convention, wrote in Turun Sanomat that he is disappointed and ashamed of the Finnish Government. ${ }^{37}$ A group of Parliamentarians requested the intention of the government, from the Parliament in 2008, whether and if yes, when, it will proceed to ratify it. The response by the minister of Justice, Tuija Brax, does not provide a definitive answer and it seems that the government does not feel obliged to give any answers. ${ }^{38}$ In the Finnish Human Rights Forum in April 2008, Brax and in 2009, both the minister for foreign affairs and the minister for justice promised to find a solution by the end of the year 2009. ${ }^{39}$ In the beginning of the year 2011, Brax announced that the ratification process of all indigenous peoples' conventions (UN Declaration on the Rights of Indigenous Peoples, ILO 169 and the Nordic Sámi Convention) will not be completed during this government. She blamed the resistance by the Centre party and especially Paavo Väyrynen, Minister for Foreign

37 Martin Scheinin, Opinion, Turun Sanomat 29.10.2008.

38 Written request on the ratification of the Nordic Sámi Convention to the Spokesman of the Parliament KK 826/2008 vp - Tuula Peltonen /sd ym. on the 7.11.2008 and the answer by the ministry of justice, 27.11.2008.

39 Personal communication with Minister Stubb in the NGO hearing on the Finnish Human Rights Policy. Mr. Stubb regretted the slow advancement of the rights of Sámi 10.3.2009. 
Trade and Development, whose electors are Finnish-born residing in the county of Lapland. ${ }^{40}$

Finland has also endured a great deal of international pressure: 36 times individual Sámi reindeer herders either from Finland, Sweden or Norway have filed a complaint with the UN Human Rights Committee ${ }^{41}$ and the government has received a warning that it should not continue with such economic activities that harm the Sámi traditional way of life (HRC 2001). Also the High Commissioner for Human Rights of the Council of Europe and the UN Special Rapporteur on Indigenous Issues have had to intervene, in for example, a case where the Finnish Forestry Company Metsähallitus was logging in a reindeer winter grazing area and forbade this activity for the next 20 years. ${ }^{42}$

Interestingly, instead of focussing on political or economic rights, the Finnish State has been active in promoting language and culture rights for Sami and that has worked as an effective deterrent to resolving the problem that is tied to the fact that Sámi have rights but the state does not want them to be equal. If they would have equal rights, would it look like they had more rights? With the rhetoric, also present in the country reports of Finland to the international human rights law instruments, which stresses that the government is 'doing its best' in settling the dispute on the rights of Sámi, the country is saving face in the international arena. Negative media reports and a general national lack of knowledge about the specific needs of the Sámi insure that there is no active movement putting pressure on the Finnish government. This approach is also visible in the Finnish 'efforts' to implement the Sámi Language Act of 2003/1086 discussed below.

\subsubsection{National laws and ways to sidestep their provisions}

The process towards recognising Sámi languages as worthy of protection took several decades $^{43}$ and it was not before the beginning of the 1990s that the Sámi languages

40 Helsingin Sanomat: 'Alma Media: Suomi ei hyväksy YK:n alkuperäiskansojen sopimusta' (Alma Media: Finland does not approve the UN Declaration on Indigenous Peoples), 21.1.2011, http://www. hs.fi/kotimaa/artikkeli/Alma+Media+Suomi+ei+hyv\%C3\%A4ksy+YKn+alkuper\%C3\%A4iskansojen +sopimusta/1135263201981, accessed in February 2011.

41 Only 7 of the cases have been accepted as admissible, see the database http://www.worldlii.org/ int/cases/UNHRC.

42 The letter was signed by the Special Rapporteur on the situation of human rights and fundamental freedoms of indigenous peoples, Rodolfo Stavenhagen of Mexico. See also Matti Huuskonen, Reindeer disputes in Finnish Lapland attract attention of UN, Helsingin Sanomat 26.10.2007, http://www.hs.fi/ english/article/Reindeer+disputes+in+Finnish+Lapland+attract+attention+of+UN/1135231431745, accessed in May 2010.

43 In Sweden and Finland the demand was tied to the growing number of refugees and asylum seekers who received home language / mother tongue teaching outside the school curricula for 2 hours a week. See Toivanen 1995. 
and culture finally gained a secured status in the legislation of all Nordic countries. Before the 1990s, many Sámi people could not learn the language they considered to be their (political) mother tongue (Svonni, 1996; Rosjo, 1997:6). In Finland, language legislation was amended in 1991 to create better chances for the Sámi to learn their languages in schools. ${ }^{44}$ In 2003 the language law was revised radically in order to ensure that all local authorities and some state authorities provide services in the Sámi languages. ${ }^{45}$ The number of Sámi speakers is no longer declining rapidly, although for most Sámi languages the legislation has come too late. The number of pupils who express interest in learning Sámi languages has grown steadily as parents become educated and informed about the importance of minority language instruction but at the same time, the number of students receiving education in Sámi has declined from 553 pupils to 483 pupils (Saamelaiskäräjät 2009:13).

In 2009 the Ombudsman office for Minorities commissioned a report on the situation of Sámi language learning in the capital city area. The report gave alarming information indicating that the learning of Sámi has not become more accessible since most of the Sámi speaking children (ca. 70 per cent) now are born outside the Sámi homelands where the Law on Sámi Cultural Autonomy applies. According to another report by the Finnish Sámi Parliament, the number of Sámi living outside of the homelands has doubled between the years 1983-2007 (Saamelaiskäräjät 2009:8). Outside of the official home territory, Sámi language is taught as any other immigrant language, as part of a mother tongue education program, which equates to 2.5 hours a week if a group of 4 children is established and a teacher found (Opetusministeriö 2007).

It is fair to state that the language rights of the Sámi are not being fulfilled in the way envisaged by the constitution and set out in the Sámi Language Act (SeurujärviKari 2010). This is due, not only to a lack of Sami-speaking staff employed by the municipal and state authorities of the Sámi Homeland, but to the main problem that is created by oblivious attitudes by local authorities: The National Discrimination Tribunal has, on the request by the Ombudsman for Minorities, investigated cases against the city of Rovaniemi and the municipality of Enontekiö (cases Decision ref 2008-25/Pe-2 and Decision ref 2008-367/Pe-2). Both were found guilty of not offering services and education in Sámi.

Irja Seurujärvi-Kari, a university teacher and the long-term vice-president of the Finnish Sámi Parliament, also accuses the National Productivity Program, which aims at improving the basis for competition and achieving higher results by Finnish authorities and companies. According to her, the goals of the program make it difficult to increase the proportion of services in Sámi because support for minority languages

44 L 25.1.1991/171. Finnish Law on changing School legislation (Laki peruskoululain muuttamisesta). 45 The Sámi Language Act 2003, http://www.finlex.fi/en/laki/kaannokset/2003/en20031086, accessed in February 2011. 
is costly. She states that '[ ] the Sámi language does not have the status of a proper subject or language of instruction in schools. For years, the Sámi Parliament has requested the Ministry of Education to correct the situation by discarding the regional restriction applied to the special funding of Sámi education' (Seurujärvi-Kari 2010). Nevertheless, a least ten schools have been closed in the Sámi home region, due to the low number of pupils (Saamelaiskäräjät 2009:10). If those international agreements to which Finland is a party and those laws that are currently in force in Finland would be taken seriously, then schools in which minority languages are taught should deserve another treatment than schools which operate in majority languages only. Moving Sámi speaking children to bigger schools means that the connection to Sámi languages is severely endangered, too.

A commonly shared opinion among Sámi activists interested in education is that '[w]hile the statutory status of the Sámi is satisfactory in Finland, the law is not adequately enforced' (Näkkäläjärvi 2010). Certainly there are efforts to revise the laws, too. But the actual problem is less the law than the fact that the state is not taking responsibility for the Sámi situation but instead, hopes that the difficulties will disappear, thus justifying delay tactics.

Many Sámi activists are disappointed with the weak role the Sámi have in their own institutions. The Finnish Sami Parliament is entrusted with matters of culture and traditions, whereas political and financial matters have always been left to the states, who thus actually direct the development of Sámi movements. Before the Law on Cultural Autonomy was passed in Finland in 1995, Pekka Aikio, the president of the Finnish Sámi Parliament complained, 'The only thing the delegation was allowed to decide independently was the dates of the meetings!' (Aikio 1992:17).

Also the new president of the Sámi Parliament, Klementti Näkkäläjärvi (2010) who is considered to be much more moderate than Pekka Aikio said very precisely:

The Sámi Parliament has a very limited genuine decision making power; it is restricted solely to the distribution of certain granted appropriations. The main means of the Sámi Parliament's pursuit of policies are negotiations, pronouncements and initiatives. The present right of self-determination is limited to the presentation of shared opinions and common representation through the Sámi Parliament. The right to self-government as a people is not fulfilled, because self-government is restricted to language and culture only. It does not apply to protection of Sámi livelihoods, though these, as part of the Sámi culture, enjoy legal protection granted by the Constitution of Finland.

There are laws protecting the Sámi and the government has committed itself to taking responsibility concerning the maintenance and development of the future of the Sámi. They enjoy a cultural autonomy in their home region; their languages are protected under a specific language act. The reindeer herding is regulated in several laws as are other agreements securing living in the Sámi homelands. On this level the Finnish state shows considerable interest in supporting the indigenous minority. At the same time, Finland has not signed or ratified the major international treaties 
to protect indigenous peoples and enters time after time into conflict with local Sámi and international actors in matters concerning land use in Lapland. Finland does not want to give up the profits from the forest and mining industry in Lapland, neither does it want to let Sámi representation to participate in the planning of these economic activities nor in the profit-sharing. The international reputation of Finland has suffered because the promises Finland makes in international fora are at odds with the factual treatment of the Sami: none of the laws were realised without repeated demands by Sámi individuals and organisations. The 'power' of the majority society appears as a pressure to conform: Sámi representatives are constantly told to settle for what they have already attained, cultural rights. But giving up demands for land rights would not only mean giving up the international agreements' standards but ultimately the Sámi way of life would disappear completely when reindeer herding, fishing and hunting have become professional activities that undermine the traditional economy, and with it a traditional way of life.

\subsection{Roma - a persistent underclass}

To understand the situation of the Roma today, one has to have an understanding of the length and severity of racism targeted at Roma people. One question that has been persistently posed by those sympathetic to their situation is, 'why do Roma not protest against the minoritisation and marginalisation more openly?'

According to historical records, the Roma immigrated through Sweden and Baltic countries to Finland around 500 years ago. The history of discrimination against the Roma in the Kingdom of Sweden to which Finland belonged until 1809, is long: even until the 1750s Roma who were found loitering somewhere could be hanged and they could be convicted on the grounds of a nomadic lifestyle (Hirvonen 2008:2). The time when Finland was a Grand Duchy of Russia was characterised by strong assimilation efforts against all different nationalities residing in Finland, including the Roma (Pulma 2005:460). According to Camilla Nordberg (2007: 57), the Roma were not only considered to be a social problem but also a problem for forging national identity: their language and culture were defined as foreign, and thus they were perceived to be perpetual strangers. Within this context the state took efforts to 'solve' the problem of Roma cultural difference (Nordberg 2007:51). After the Second World War (in which many Roma served) and the loss of the Eastern part of Karelia to the Soviet Union, a large number of Roma was, together with other Finnish refugees, resettled in Finnish municipalities. Many Roma families, who had been living well integrated in cities such as Sortavala (which became a Soviet city after the war), found themselves homeless and unemployed.

After the war, the socioeconomic situation of the Roma was bad, particularly concerning housing and education (Pulma 2006). Governmental organisations were 
established in order to improve the living conditions of the Roma but listening to the Roma themselves describe their actual needs and wishes of Roma people. For example, because discrimination was so persistent, many parents did not want their children to attend the majority schools, where they feared they would be victimized. Around this time, the oldest organisation serving Roma, the Romano Missio, which had been founded in 1906 as a Christian charity to 'help and guide Roma people' stepped up its activities. ${ }^{46}$

The Roma's common physical distinctiveness serves to underline their 'difference': they have darker hair and skin than most Finns. In addition, many Roma women wear distinctive clothes (long and fancy velvet dresses) that identify them immediately as members of the Roma group. Over the years, Roma have been closely associated with certain professions such as equine-related businesses (trot, shoeing, horse health services), copper smiths, seasonal work at farms, lace works, and fortune telling-professions which are not tied to any geographical places and can be continued wherever necessary. Roma were often portrayed as premodern, and thus as out-of-sync with a modernizing society. Even though many Roma families did settle down and earn their livelihood in quite common 'Finnish' professions, the general stereotype stamped upon them depicted their culture as contributing to their incapacity for normal rational living.

When Finland became independent in 1917 all population groups became Finnish citizens, including all Roma people who resided in the country. Different efforts were undertaken to assimilate the Roma population, which included taking children into custody to learn the Finnish lifestyle (through educating Roma to give up their 'curious habits' and 'become normal') (Komiteamietintö 1900:3). The effects were contradictory: the Roma became an even more closed community. Research conducted on Roma was undertaken basically by non-Roma and all the expertise guiding the efforts to domesticate 'the wild Roma' ignored inside knowledge about the Roma. An Advisory Board on Gypsy Issues (later Advisory Board for Roma) was established in 1956, which also included several persons with Roma background. But, in its beginning, the working agenda was clearly defined from a majority perspective (Söderman 2006:11).

Since the 1970s there has also been a shift in Roma politics, and Roma have become more involved in Roma organisations and in different state committees, which have tried to 'solve the Gypsy problem'. Different efforts have been undertaken first to force and then to persuade the Roma to send their children to school and keep them there. Also in the field of housing there have been, especially since the 1970s, programs to guarantee equal housing rights to Roma people and also to pay attention to their

46 Romano Missio (founded as Gibsy Mission) cooperates closely with the Finnish Lutheran Church, see http://www.romanomissio.fi/index.htm, accessed in May 2010. 
cultural needs. ${ }^{47}$ Interestingly, despite their own participation, Roma as a people have remained at the margins of Finnish society. The last statistical research on the living conditions of the Roma people was undertaken in 1970 and it revealed a huge gap in the living standards between the mainstream and the Roma populations (Paananen 2009). Due to privacy laws, such research has not been possible anymore because the law does not permit questions about ethnicity. Still the fact is, however, that the same or similar problems continue, tangled with discrimination, low education, cultural change and alienation (Hirvilammi and Laatu 2008). According to 2007 statistics, most of the discrimination cases in district courts were filed by Roma. Most of the cases were addressing the right to enter a restaurant or to right to housing (Aaltonen, Joroinen and Villa 2008:31).

Regardless of all the educational programs, which have been in place since the1970s, the marginalisation of Roma has not diminished. A study of the state of the education of Roma children in Finland concluded that despite all the hard work, the Roma are placed into special education, drop out of school or repeat the class much more often than mainstream pupils (Opetushallitus 2004:5-6). Discrimination studies, the few that exist, also indicate that the discrimination of Roma continues at a disturbing frequency. For example, according to a recent poll among 300 capital city area company leaders, only a half would hire a Roma. The reasons given by the employers are low educational attainment and lack of work experience. 12 per cent would not hire a Roma in any case, while 70 per cent of Roma think that prejudice is the main reason for unemployment (Syrjä and Valtakari 2008). They face discrimination in the area of employment and housing (Hedman 2009a) and are continuously subjected to everyday discrimination in the streets. The prejudices of the majority population and the weaker economic position of the Roma also make it hard for them to find adequate accommodation in the private housing market (Ministry of Social Affairs and Health 2004:9). In the current climate that is more favourable to diversity, a new tendency has arisen that promotes the involvement of the Roma in the planning phase of projects. There is some evidence to indicate that this recent shift has improved the quality of projects as well as the interest of Roma to participate in them.

\subsubsection{Blood feuding}

There have always been Roma persons and families who have enjoyed great respect among the majority population and Roma have carried out ethnically distinct, and

47 Finnish Roma have often been characterised as the most traditional Roma on Earth. Many families maintain traditions which prescribe that old people cannot use the same bathroom as the young or that young people may not live in an apartment located above the old people. After the death of a person, the family has to move to another 'clean' flat, etc. see i.e. Huttunen and Viljanen 1976. 
for the majority's well-being, important professions. But as an ethnic group, people classified as Roma, have suffered under negative stereotypes, open discrimination and racism even though they share a common history with Finns. Those persons with plenty of influence and power have sometimes served as ethnic brokers (Toivanen 2001) between the majority and the minority. I shall get back to this matter later and discuss how this position has empowered the Roma both in respect to the majority as well as with minorities.

When on the one hand it is important to underline that Roma have not selected a lower standard of living and not voluntarily chosen to be targets of racism and discrimination, it is equally relevant to underline that they have found ways to endure the situation in which laws do not equally protect them as they would other Finnish persons. This may be the main reason that Roma can be described as a separate ethnic community with internal specific 'laws' governing their life.

As Aulis Aarnio (1989:16-17) shows, existing power relationships always dictate the existing laws, and particularly impact the ways in which laws are interpreted. There are reasons why Roma have continued to act as an autonomous body inside the Finnish state. Because the national laws that focus on protecting the individual do not work particularly well for the more communally-oriented Roma, justice by their own hand has evolved as the customary system of justice among them. The leading families have been the care-takers of traditions: for example the Roma who lived by travelling in a geographical area from house to house to secure their living, did not want other (Roma) families to come to the same areas to take their share of jobs and business. Neither did they want other Roma to come and ruin their reputation by stealing or otherwise misbehaving. If a new Roma family entered the 'area' of another Roma family, they were expected to ask for permission (Grönfors 1977). Today, in a modern economy when no one is depending on travelling from house to house to make their living, this moving permission has become a relic, but which is used especially in the city areas to hinder new Roma people to move to their neighborhoods. Of course, this can also be explained rationally: the settled Roma are always afraid that newcomers will do something bad and therefore their lives will get more difficult: the Finns will just think that it's Roma who stole etc. and accuse all Roma, not the specific individual who in fact committed the crime.

Another example of difficulties between culturally developed traditions and modern understandings of equal laws is the case of blood feuding, which has been addressed recently in the majority media. According to Roma tradition, if A kills or severely injures $B$, the family of the person A has to immediately (even if it would be in the middle of the night) move away and take care that they never encounter the member of family B. This is the way to show respect to the family of the victim. The blood feuding is not about bringing peace between the families but to show the strength of the kin group (Grönfors 2001:168). Today, however, some people feel that, as they themselves have not harmed anyone, for example, a wife or sister of a murderer, who wishes to take no responsibility for the crime by the husband or 
brother who (often in a drunken condition) killed an outsider, they do not want to begin avoiding. This is penalised by the Roma; it is for many difficult to accept that someone would not obey the customary law. If a person, who is afraid of revenge in the sense of blood feuding, would seek help and protection with the Finnish police force or other authorities he or she would be punished by other Roma. As Grönfors (2001:154) stresses, the police shall in no circumstance be involved and the revenge action shall not harm any Finns, not even the Finnish spouses of Roma, but the children from mixed marriages are considered Roma in this tradition. The transition caused by integration of Roma to Finnish culture, means today that there is often a serious conflict between those who wish to enjoy equal rights according to Finnish laws and those who distrust the state and wish to continue with the Romani internal legal system. Of course those who occupy powerful positions in the customary legal system are extremely reluctant to obey the Finnish laws already for the reason that inside of the Roma legal system they enjoy power whereas in the Finnish system, they are the outcast.

\subsubsection{The Roma language - revitalisation efforts of a secret code}

The Roma language spoken in Finland has been considered a secret language and the Roma were, according to their own customary law, not supposed to teach it to outsiders. In the 1970s the number of people speaking the language had already become very low and as refugee children started to receive mother tongue teaching in the schools, Romani language lessons were also proposed. The education of Roma language as a mother tongue was inspired by the example provided by Sweden, where Finnish Roma was taught as an immigrant language. The first Roma teachers were Finnish immigrants to Sweden from the 1960s and 70s who returned to Finland to teach. In the elementary schools, Romani teaching was first carried out in afternoon clubs and since 1989 Romani culture and language have been offered by parental request as mother tongue classes.

The constitutional reform in 2000 levelled the right for Roma to maintain and develop their own language and culture as a constitutional guarantee. This was also bolstered by the Decree on Children's Day-care, which enabled support for Romani language and culture, and by the Basic Education Act, which confirmed the place of the Roma language as a mother tongue. The law mentions the right of the Roma to maintain and develop their own language and it obligates the public authorities to back this. This is a substantial support for improving the situation of the Roma. In ratifying the European Charter for Regional or Minority Languages Finland identified Romani as a non-territorial minority language, and in ratifying the Framework Convention for the Protection of National Minorities, Finland identified the Roma and the Sámi as traditional national minorities. 
It may be unfair to evaluate the workings of law after such a short time in force. However, it seems worrisome from the perspective of the Roma that the number of Romani language speakers continues to decline (Opetushallitus 2004). According to a report carried out by the Romani Education Unit of the National Board of Education in 2001 only eight percent of Roma children attending primary school receive Romani lessons (Ministry of Social Affairs and Health 2004:7), whereas today the number is less than 5 per cent (estimation by Granqvist 2006). Recent decades have seen the development of teacher training courses in Romani, the production of Romanimedium teaching materials and the efforts to encourage its use among the Roma through things such as summer schools.

According to the study carried out by the National Board of Education in 2000 and 2001, 19 per cent of Roma children repeat a class, 5 per cent drop out of school completely, 12 per cent change their school during the school year, 50 per cent receive special education, 2 per cent attended pre-school classes and only less than 6 per cent received education in Romani language and culture (Opetushallitus 2004). The numbers are extremely high and tell a simple story: the education of Roma has not improved despite of all the projects and programs. As of 2011, not a single person has graduated from the teachers' education unit with the Romani language as their teaching language, which means that there is not a single teacher with formal competence to teach Romani in Finland. ${ }^{48}$

\subsection{Power as a theory and a practice}

The question of why the Finnish Roma people have remained so marginalised is often explained on the basis of factors having to do with cultural differences: they want to keep to themselves and even their language is so well protected that outsiders cannot learn it. It is certainly true that the Roma have 'kept to themselves' but less due to cultural reasons. As has been shown above, many Roma have lived integrated lives as respected neighbours in many Finnish communities over an extended period of time. They have had traditional professions and big families. The family relationships have been extended to other towns and regions and formed a network with strong ties and ruled within the hierarchical power relationship inside the network. At the same time, especially after the Second World War, when Finland lost eastern Karelia to Russia, many more Roma arrived as internally displaced persons and started looking for livelihoods and places to live. This formed one basis for the travelling life-style: a periodical workforce was necessary in the Finnish countryside and Roma families had their own annual travelling routes. They knew those houses that offered

48 The University of Helsinki is currently participating in a three-year EU project Qualirom led from the University of Graz, with aim of improving the quality of teaching Roma languages in Europe. 
work and a place to wash and stay. In return they took care of diverse chores on the farms. Modernisation and industrialisation has change the lifestyle of all habitants of Finland, and also the Roma conditions of living have changed, in that they have had extreme difficulties to enter the new kind of job market that requires educational credentials. The Finnish policies have been highly ambiguous: on the one side are the policies driving for equal opportunity and cultural neutrality, while on the other side there are policies stressing the cultural (or even human?) difference of Roma, explaining how and why they have to be treated differently in the day-care, school or workplace. Either way, the Roma have only had a marginal part in revising the policies and only such Roma who have either grown in Finnish families or are from powerful Roma families with in-group prestige have been included. These cultural brokers may, in a worst case scenario not have any real interest in empowering the Roma.

Similar arguments can be made about the Sámi. Finnish laws have dictated the Sámi way of life for such a long time and the Sámi activists have been educated in the Finnish system. Asking for a real 'Sámi interest' may be an impossible task. Those Sámi who mobilise international bodies to shake the picture of the Finnish state as a Sámi or even minority friendly state are often dismissed, even within their own ethnic group. Both Sámi and Roma try to find ways to stay in contact with the state authorities, but acquiring the reputation as 'difficult' means to be left outside of the sphere of decision making completely. The cultural brokers have to very carefully find ways of balancing between the two ends of the spectrum: the needs and demands of the Finnish state and what could be defined as a true ethnic interest.

Charles Tilly (1991) posed the question that many others have kept asking for years before and after: Why do subordinates comply, why are they not resisting continuously? Why would e.g. the Roma people accept the amount of discrimination against them without going to streets and protesting against the injustice? Why do they not make both the out-group and in-group discrimination public? Why would the Sámi obey the Finnish politics e.g. in land use questions which lead to a complete fading of the traditional way of life in the North and not address the injustices more openly in the public sphere? Why are they not openly bringing their cases to the streets of the capital city of Helsinki where the decision-makers pass?

Tilly's famous check-list for possible answers begins with the statement that it might be that the premise is incorrect: that subordinates rebel all the time but in covert ways, or they get something for agreeing to be subordinate, or subordinates are so closely part of the given system that they do not recognise themselves as subordinates, or as a result of mystification, repression or lack of alternative ideological frames, the subordinates remain unaware of their true interests, or they lack means and resources, ability or all of the above-mentioned. Steven Lukes (2005) commented on Tilly's answers saying that of course all the above mentioned in various combinations apply. But the answer that makes Lukes curious is that people may not know their 'true interests'. This is what Lukes has called the third dimension of power which 
is the power 'to prevent people, to what-ever degree, from having grievances by shaping their perceptions, cognitions and preferences in such a way that they accept their role in the existing order of things' (2005:11). The third dimension of power, the dimension in which no action is visible or even necessary, when things are as they are and nobody feels the necessity to question the situation, has been my interest in this project and this article.

My empirical assessment took a critical look on the following three dimensions of power following Steven Lukes' (2005) theory. The first dimension of power, which he calls the pluralist view of power, stresses concrete and observable behaviour. For Dahl (1958:466) who is one of the prominent protagonists of this approach, power can be analysed only after 'careful examination of a series of concrete decisions'. The clear limit of this view is that it is restricted to the observable decision making and is not able to grasp the agenda-setting behind it. The two-dimensional view of power is a critical response to the one-dimensional and tries to include the question of how certain biases are mobilised in the agenda setting before the decision makingprocess can even begin. For Bachrach and Baratz (1970:43-4), these biases are a set of predominant values, beliefs, rituals, and institutional procedures that operate to the benefit of certain persons and groups, at the expense of others. This approach makes it possible to analyse both decision-making and non-decision-making. It allows the investigation of questions related to agenda control and ways in which potential issues are kept outside of the political process. But the same restriction remains as in the first model: Only observable conflicts, even though both overt and covert, can be analysed. In my view, a three-dimensional approach, as envisioned by Lukes originally in 1974, is necessary for a study such as this one, which focuses not only on clear majority-minority relationships but also on the intermingled liaisons inside these categories and on the mixed and multiple co-operations between individuals identifying with several categories. This 'radical view' allows for a power analysis without an observable conflict. This approach means a study of notions, such as the public sphere or civil society, as hegemonic concepts, which control and change the new topics before they are allowed to enter the public sphere or to be included as actors and interests of civil society. ${ }^{49}$

One can identify at least two strong research trends here. One which may be best associated with James Scott (1990) who says that whatever we see, hear and believe, people are constantly rebelling and resisting, even though in covert ways. The other starting place is Foucaultian theory. Michel Foucault (1978) argues that domination cannot be escaped, it is everywhere and there is no freedom of thought or reasoning independent of it. Contrasting these two and addressing the question whether we can ever tackle the true interests of people, I have discussed the ways in which the Finnish Sámi and Roma tackle power and their relationship to a hegemonic Finnish state.

49 See here the feminist critique of the public sphere, i.e. Bell 1999. 
In concluding, the Finnish state is officially committed to creating an equal society. The non-discrimination and respect of equality are defined today as the cornerstones of Finnish society. This has been effective in the way that most Finnish people themselves define equality as one of the true markers of Finnish identity. When it comes to minority interests, Finland has pursued a policy which has tried to include difference-demands within the general policies: to each specific differenceclaim, there is an advisory board where people of the 'difference-claim-makers' sit next to Finnish authorities from relevant ministries to discuss matters of mutual concern. This sounds like exemplary inclusion politics where, e.g., the Sámi and the Roma representatives have the right to participate in the decision-making process. My assessment is, however, that as this inclusion is initially defined from a majority vantage, it only works towards further undermining minority identities. The Sámi have been granted cultural and language autonomy at the cost of rights to land and natural resources. The autonomy is effective in an area where fewer and fewer Sámi can afford living traditional ways of life because their right to gain their livelihood in their traditional professions has been made ever more difficult. 70 per cent of Sámi children are born outside of the area of the cultural autonomy homelands. The right to difference, to a different way of life, has been compromised with negative consequences, endangering their future as indigenes. When few or no Sámi pursue traditional livelihoods, will they still be granted rights as indigenous peoples?

The Roma have been granted sameness rights; they cannot be segregated anymore without violating the non-discrimination law. Several official bodies discussing the matters concerning non-discrimination in housing, employment, family-life and education have been established and representatives of Roma people are in most cases involved. There are strong promises to level the way for Roma to become equal citizens. At the same time, the hundreds of years of continuing racism against the Roma, has developed a segregated Roma community with its own rules and laws. The response of the Finnish political establishment has been to develop guidebooks for Finnish employers, teachers and health personnel about how to face the difference represented by Roma. Even those Roma who would like to break out from the rather strict cultural codes of the Roma community face the difficulty that they are treated by authorities as Roma (with whom you shall not speak on certain topics and whose in-group discrimination shall not be noticed officially). They seem to be doomed to difference: Instead of ensuring that the Roma way of life could become a part of Finnishness, they are categorised as outsiders.

The real interests of these two minorities remain untouched in the state politics. Recognising their needs and guaranteeing them rights to both equality and difference is ever more difficult when the minorities are represented in official bodies by persons who are quite assimilated in the 'Finnish-way-of-thinking'. Those who argue for another perspective are often dismissed as difficult persons and are excluded from ministry-led advisory boards. If the answer to the problem is even more participation by minorities, it would still be an open question whether a state with a homogenous 
self-image would be able to change: If participation is defined in terms set by the majority, the marginalization of minority interests will continue. The future will show whether the Sámi and Roma will radicalise their approach and find a platform to address difference-demands on a more effective manner or whether they will fade away and get dissolved into a homogeneous version of 'Finnishness'.

\section{References}

Aaltonen, M., M. Joronen and S. Villa. 2009. Syrjintä Suomessa 2008. Helsinki, Finland: Ihmisoikeusliitto.

Aikio, M. Sopimattomat saamelaiset. 2006. Tiedepolitiikka 4: 21-34, http://elektra.helsinki.fi/ se/t/0782-0674/31/4/sopimatt.pdf.

Aikio, S., Aikio-Puoskari, U. \& Helander J. 1994. The Sámi Culture. Lapin Sivistysseuran Julkaisuja 49. Helsinki: Painatuskeskus.

Anaya, J. 2010. Opening Statement of the Special Rapporteur on the situation of the human rights and fundamental freedoms of indigenous people, 15.4.2010 in Rovaniemi, Finland.

Bachrach P. and M.S. Baratz. 1970. Power and Poverty - Theory and Practice. New York Harper and Row..

Bell, V. 1999. “Mimesis as Cultural Survival: Judith Butler and Anti-Semitism.” Theory, Culture \& Society 16(2):133-61.

Boxberg, K. and T. Heikka. 2009. Lumedemokratia. Helsinki, Finland: WSOY.

Council of Europe. 1995. Framework Convention on the Protection of National Minorities, ETS 157, 1.2.1995.

Dahl, R.A. 1958. “A Critique of the Ruling Elite Model.” American Political Science Review 52(2): 463-469.

Foucault, M. 1978. Discipline and Punishment: The Birth of the Prison. Brighton, UK: Harvester. Granqvist, K. 2006. Selvitys Suomen romanikielen nykytilasta sekä kielentutkimuksen ja -huollon tarpeista. http://www.kotus.fi/files/729/romaniselvitys-1.pdf, accessed in May 2010.

Grönfors, M. 1977. Blood feuding among Finnish Gypsies, Research Report, Department for Sociology, University of Helsinki.

. 2001. “Institutional Non-marriage in the Finnish Roma Community and Its Relationship to Rom Traditional Law.” Pp. 149-169 in Weinrauch, W. O., Gypsy Law-Romani Legal Traditions and Culture. Berkeley: University of California Press.

Hedman, H. 2008. Romanikieli ja -identiteetti. Romanikielen tila tänään. 2.9., http://www.oph.fi/ binary.asp?path=1;443;87258;87261;87266;87275\&field=Fil . 2009a. Suomen romanikieli: sen asema yhteisössään, käyttö ja romanien kieliasenteet, Kotimaisten kielten tutkimuskeskuksen verkkojulkaisuja 8, Kotimaisten kielten tutkimuskeskus, Helsinki. . 2009b. Romanikielen kielipoliittisen seurannan vuosiraportti. Kotimaisten kielten tutkimuskeskus 1.1.-31.12, http://www.kotus.fi/files/1385/Romanikielen_kielipoliittinen_ seuranta_2009.pdf, last accessed in May 2010.

Hirvilammi, T. and M. Laatu. 2008. Epäoikeudenmukainen kohtelu on romaniasiakkaiden arkea, In: Tuuli Hirvilammi and Markku Laatu (eds.) Toinen vääryyskirja. Helsinki: Kela, 183-198.

Hirvonen, H. 2008. Suomen Romaniväestöm oikeusaseman muutokset vuosina 1900-1980. Pro gradu -tutkielma, Oikeustieteellinen tiedekunta, Helsingin yliopisto 21.6.

HRC 1992. Views of the Human Rights Committee under article 5, para. 4, of the Optional Protocol to the International Covenant on the Civil and Political Rights, UN doc. No. CCPR/C/52/511/1992. 
Huttunen, K. and A. M.Viljanen. 1976. Mustalaiset - vähemmistönä Suomessa. Kouluhallitus.

ILO International Labour Organisation's Convention 169 concerning Indigenous and Tribal Peoples in Independent Countries, adopted in 1989.

Jaakkola, M. 2009. Maahanmuuttajat suomalaisten näkökulmasta, asennemuutokset 1987-2007. Helsingin kaupungin tietokeskuksen tutkimuksia 2009:1.

Khleif, B. B. 1993. Minoritization of Languages in Their Traditional Historical Territories: Issues of Autonomy and Identity in the Nation-State. Sociologia Internationalis 31(2):159-178. Berlin: Duncker u. Humblot.

Kuokkanen, R. 2008. Sami Rights Policy in Finland: Delay Tactics until the Problem Disappears? Blog entry on the 10.10.2008: http://rauna.wordpress.com/2008/12/10/human-rights-policyin-finland-delay-tactics-until-the-problem-disappears, accessed in May 2010.

Lehtola, V-P. 2004. The Sami People: Traditions in Transition. Trans. Linna Weber Muller-Wille. Fairbanks: University of Alaska Press.

Lepola, 0. 2000. Ulkomaalaisesta suomenmaalaiseksi. Monikulttuurisuus, kansalaisuus ja suomalaisuus 1990-luvun maahanmuuttopoliittisessa keskustelussa. Helsinki: Suomalaisen Kirjallisuuden Seuran Toimituksia 787.

Lukes, S. 2005 Power a Radical View. 2 ed. New York: Oxford University Press.

Mahler, C. 2009. “Is Human Rights Education a Means of Supporting Minorities?” Pp. 187-201 in C. Mahler, A. Mihr and R. Toivanen, The UN Decade for Human Rights Education 1995-2004 and Its Contribution to the Furtherance of the Rights of National Minorities, Berlin: Peter Lang Verlag.

Mahler, C., A. Mihr, and R.Toivanen. 2009. UN Decade for Human Rights Education 1995-2004 and Its Contribution to the Furtherance of the Rights of National Minorities, Berlin: Peter Lang Verlag.

Mann, M. 1999. "The Dark Side of the Democracy: The Modern Tradition of Ethnic and Political Cleansing." The New Left Review, Issue 235, May/June.

Ministry of Foreign Affairs 2010. The Third Periodic Report on the Implementation of the Framework on the Protection of National Minorities. February 2010.

Ministry of Justice: Act on the Sámi Parliament 974/1995, adopted 7.7.1995, last amended 1.1.2004.

Ministry of Social Affairs and Health: Finland's Romani People. Brochures of the Ministry of Social Affairs and Health 2004: 2, $4^{\text {th }}$ edition, http://www.stm.fi/c/document_library/get_file?fold erld=28707\&name=DLFE-3777.pdf\&title=Finland_S_Romani_People__Finitiko_Romaseele_ en.pdf, accessed in May 2010.

Nickul, K. 1984. Onko saamelaisilla tulevaisuutta? (Gibt es eine Zukunft für die Saamen?) In: Bálggispolku. 1932-1982 Lapin Sivistysseura, Jyväskylä: Gummerus, 45-50.

Näkkäläjärvi, K. 2010. Statement by Finnish Sámi Parliament on the Realization of Sámi People's Right to Self-Determination in Finland, Conference with the Special Rapporteur on the Situation of Human Rights and Fundamental Freedoms of Indigenous People James Anaya, Rovaniemi, April 15.

Offe, C. 1996. Homogenität im demokratischen Verfassungsstaat - Sind politische Gruppenrechte eine adäquate Antwort auf Identitätskonflikte? Peripherie 64/ 1996, 26-45.

Opetusministeriö .2007. Opetusministeriön asetus 392/2007 vieraskielisten sekä saamenkielisten ja romanikielisten oppilaiden täydentävään opetukseen perusopetuksessa ja lukiokoulutuksessa myönnettävän valtionavustuksen perusteista.

Opetushallitus. 2004. Romanilasten perusopetuksen tila, selvitys lukuvuodelta 2000-2001, Opetushallitus. http://www.oph.fi/instancedata/prime_product_julkaisu/oph/ embeds/48985_romanilasten_perusopetuksen_tila.pdf, accessed in May 2010.

Paananen, S. 2009. Neljäkymmentä vuotta kielivähemmistöjen elinolotutkimuksesta, Hyvinvointikatsauksessa 3.

Pulma, P. 2006. Suljetut ovet. Pohjoismaiden romanipolitiikka 1500-luvulta EU -aikaan. Jyväskylä. 
Rosjo, B. 1997. "Engineering a cultural comeback“. Tell Us - A Publication of the Research Council of Norway, 4-7.

Saamelaiskäräjät: Saamelaisopetus, kotiseutualueen ulkopuolella, Saamelaiskäräjien koulutusraportti nro 1, Saamelaiskäräjien koulutus- ja oppimateriaalitoimisto 2009.

Saukkonen, P. 2010. Kotouttaminen ja kulttuuripolitiikka. Tutkimus maahanmuutosta ja monikulttuurisuudesta suomalaisella taiteen ja kulttuurin kentällä. Kulttuuripoliittisen tutkimuksen edistämissäätiö. Cupore, Helsinki. (A study on integration policy and cultural policy in Finland).

Scheinin, M. 1989. Ihmisoikeudet Suomen oikeudessa. Suomen lakimiesyhdistyksen julkaisuja 189.

Scott J. 1990. Domination and the Arts of Resistance: Hidden Scripts. New Haven: Yale University Press.

Seurujärvi-Kari, I. 2010. "Sámi Children and Young People with a Particular Focus on Education and Language," Rovaniemi April 15.

Söderman, J. 2006. Läpimurron aikaa, Pp. 10-14 in S. Fridman-Korpela and A-M. Mäki (eds) Romanit toimijoina yhteiskunnassa, Sosiaali- ja terveysministeriön julkaisuja, 5, 10-14.

Svonni, M. 1996. "Sámi Language as a Marker of Ethnic Identity among the Sámi.“ In: Essays on Indigenous Identity and Rights. Seurujärvi-Kari, I.; Kulonen, U-M. (eds.). Helsinki, 105-125.

Syrjä, H. and M. Valtakari. 2008. Romanien pitkä matka työn markkinoille. Työ- ja elinkeinoministeriön julkaisuja. Työ ja yrittäjyys 22.

Tanner, A. 2011. Finland's Balancing Act: The Labor Market, Humanitarian Relief, and Immigrant Integration, MPI Country profiles January 2011, http://www.migrationinformation.org/Profiles/ display.cfm?ID=825, accessed in February 2011.

Tilly, C. 1991. “Domination, Resistance, Compliance...Discourse." Sociological Forum, 6(3): 593-602. Toivanen, R. 1995. Language is the Key and the Lock - The Meaning of Immigrant Children's Own Mother Tongue, Religion and Culture in the Integration Process. Department of Comparative religions. Helsinki University.

.2003. "Sámi People and Nordic Civil Societies." Pp. 205-216 in N. Götz and J. Heckmann, Civil Society in the Baltic Sea Region. Aldershot: Ashgate.

2007. Education on Human Rights - a Method for Inducing Global Critical Thinking, Education for Global Responsibility - Finnish Perspectives. Publication of the Ministry of Education 2007: 31, 33-45.

Topelius, Z. 1934. Maamme-kirja, 38. Helsinki: WSOY.

Vartia, M., M. Lahtinen, M. Joki, and S. Soini. 2008. Sinikka: Piinan loppu - Kiusaamistilanteiden selvittely työpaikalla. Helsinki: Työterveyslaitos.

Vähemmistövaltuutetun vuosikertomus (Yearly report by the ombudsman for minorities). Helsinki: Vähemmistövaltuutettu 2007. 